\title{
Insulin Sensitivity of Adipose Tissue and of Diaphragm in Rats Adapted to Periodic Hyperphagia
}

\author{
A. Vrána, P. Fábry, and T. Braun \\ Physiology Department of the Institute of Human Nutrition, \\ Prague - Krč, Czechoslovakia \\ Received: October 16, 1969
}

\begin{abstract}
Summary. In the present paper the authors have investigated the sensitivity of adipose tissue and dia. phragm to insulin in rats adapted to periodic hyperphagia. Insulin was administered by the intraperitoneal route in amounts that did not affect the blood sugar level. The incorporation of labelled glucose, administered simultaneously with insulin, into lipids of parametrial adipose tissue and into glycogen of the diaphragm was investigated, together with the glycogen content of the diaphragm. Moreover, the authors investigated the influence of insulin added to the medium on the glycogen content of the isolated diaphragm. It was found that adipose tissue of adapted rats responded to insulin at all levels used, more sensitively than adipose tissue of control rats fed ad libitum. On the other hand, no differences were found in the sensitivity of the diaphragm to insulin either in vivo or in vitro. The relationship between morphological and functional changes in the adipose tissue of adapted rats and the increased reactivity of this tissue to insulin is discussed.
\end{abstract}

Sensibilité à l'insuline du tissu adipeux et du diaphragme de rats adaptés à l'hyperphagie périodique

Résumé. Dans cet article les auteurs ont étudié la sensibilité à l'insuline du tissu adipeux et du diaphragme de rats adaptés à l'hyperphagie périodique. L'insuline était administrée par voie intrapéritonéale en quantités ne modifiant pas le taux de la glycémie. L'incorporation du glucose marqué, administré en même temps que l'insuline, dans les lipides du tissu adipeux paramétrial et dans le glycogène du diaphragme, a été étudiée en même temps que le contenu en glycogène du diaphragme. En outre, les auteurs ont étudié l'influence de l'addition d'insuline au

In previous work we found that in rats adapted to periodic hyperphagia the sensitivity to insulin changes. Adapted animals responded to exogenous insulin by a greater drop of the blood sugar level than control animals fed ad libitum. Marked differences were also found in the sensitivity of target organs to insulin. The sensitivity of adipose tissue to insulin judged from the stimulation of glycogen synthesis and lipogenesis was much higher in adapted rats than in controls fed ad libitum. On the other hand, muscle tissue of adapted rats responded to insulin by a smaller increase of the glycogen content than did the tissue of controls. These findings were obtained using doses of insulin that lower the blood glucose level (BRAUN et al., 1967).

Insulin administered by the intraperitoneal route influences in a marked way the metabolism of insulinsensitive tissues in the abdominal cavity, even when the doses of insulin used are 10-100 times smaller than milieu sur le contenu en glycogène du diaphragme isolé. On a constaté que le tissu adipeux des rats adaptés répondait à l'insuline à tous les taux utilisés, d'une manière plus sensible que le tissu adipeux des rats témoins nourris ad libitum. D'autre part on n'a trouvé aucune différence dans la sensibilité du diaphragme à l'insuline in vivo ou in vitro. La relation entre les variations morphologiques et fonetionnelles dans le tissu adipeux des rats adaptés et la réactivité augmentée de ce tissu à l'insuline est discutée.

Insulinempfindlichkeit des Fettgewebes und Zwerchfells von Ratten nach Adaptation an stoßweise Nahrungszufuhr

Zusammenfassung. Die Autoren überprüften die Empfindlichkeit des Fettgewebes und des Zwerchfells gegenüber Insulin bei Ratten, die sie an stoßweise Nahrungszufuhr gewöhnt hatten. Insulin wurde dabei in nicht blutzuckerwirksamen Mengen i.p. injiziert. Es wird über den Einbau von gleichzeitig verabreichter Radioglucose in die Lipide des parametranen Fettgewebes und das Zwerchfellglykogen und über den Glykogengehalt des Zwerchfells berichtet. Ferner untersuchten die Autoren die Wirkung von Insulinzusätzen auf den Glykogengehalt des isolierten Zwerchfells. Es zeigte sich, daß das Fettgewebe adaptierter Ratten auf alle verwandten Insulinkonzentrationen stärker ansprach als das Gewebe der Kontrolltiere mit freiem Zugang zum Futter. Andererseits wies die InsulinAnsprechbarkeit des Zwerchfells weder in vivo noch in vitro Unterschiede auf. Die Beziehungen zwischen morphologischen und funktionellen Veränderungen des Fettgewebes adaptierter Ratten und seiner erhöhten InsulinEmpfindlichkeit werden besprochen.

Key-words : Insulin sensitivity, feeding pattern, adipose tissue.

those needed to influence the blood sugar level. The glycogen content of diaphragm increases; and when, concomitantly with insulin, labelled glucose is administered, the effect of insulin can be observed on the diaphragm (incorporation of labelled glucose into gly. cogen), as well as on adipose tissue in the abdominal cavity (incorporation of labelled glucose into lipids and glycogen). This approach thus permits the simultaneous investigation of the effect of insulin on these two tissues in vivo and without affecting the blood sugar level (RAFAELSEN, 1964; RAFAELSEN et al., 1965).

The object of the present work was to investigate the reactivity of tissues of adapted rats to insulin in vivo, using insulin doses that do not affect the blood sugar level, i.e. under conditions where probably counterregulating factors are not involved and where the availability of glucose is not the limiting factor. 
In addition the reactivity of the diaphragm to insulin was investigated in vitro.

\section{Methods}

Female rats of the Wistar strain, weighing $180-$ $220 \mathrm{~g}$ and fed a laboratory diet (FÁBRY, 1959) were used. The animals were fed for $2 \mathrm{~h}$ a day (7 to 8 a.m.) for a period of six weeks; the controls were fed ad libitum. All animals had free access to water. Before the experiment all animals were fasted for $24 \mathrm{~h}$.

Physiological saline containing $250 \mathrm{mg}$ of bovine serum albumin $/ 100 \mathrm{ml}$ and uniformly labelled ${ }^{14} \mathrm{C}$ glucose $^{1}$ (spec. activity $75 \mathrm{mCi} / \mathrm{mmol}$ ) in an amount corresponding to $2 \mu \mathrm{Ci} / 100 \mathrm{~g}$ body wt., was injected intraperitoneally. When insulin was used it was included in the injected fluid in the following amounts: 125,500 and $2000 \mu \mathrm{U} / 100 \mathrm{~g}$ body $\mathrm{wt}$. Tissue specimens were collected under pentobarbital anaesthesia $150 \mathrm{~min}$ after the intraperitoneal injection. The diaphragms were frozen on a block of solid carbon dioxide and weighed; and the glycogen was then extracted by boiling in $30 \% \mathrm{KOH}$ for a period of $60 \mathrm{~min}$ and subsequently reprecipitated three times with $60 \%$ ethanol. After dissolving the precipitated glycogen in distilled glycogen obtained from the diaphragm and of the lipids from the adipose tissue was measured using a scintillation spectrometer (Nuclear Chicago).

The sensitivity of the diaphragm to insulin was also investigated in vitro. The rats were killed by decapitation after a 24-hour fast. One hemidiaphragm from each animal was incubated in an insulin-free medium (the control), and the other in a medium containing insulin. The incubation medium was Krebs-Ringer bicarbonate buffer ( $\mathrm{pH} 7.4$ ), equilibrated with $95 \%$ $\mathrm{O}_{2} / 5 \% \mathrm{CO}_{2}$ at $37^{\circ} \mathrm{C}$ in a Dubnoff metabolic shaker (90 cycles/min). The incubation medium contained bovine serum albumin $(250 \mathrm{mg} / 100 \mathrm{ml})$ to prevent adsorption of insulin on glass. The concentrations of glucose and insulin are given in Table 3. After incubation for $120 \mathrm{~min}$, the glycogen content of the diaphragms was assessed.

\section{Results}

It is apparent from Table 1 that insulin in all doses used stimulated the incorporation of labelled glucose into lipids of parametrial adipose tissue considerably more in adapted rats than in control rats fed ad libitum. No differences were found between control and adapted

Table 1. Effect of crystalline insulin on lipogenesis from ${ }^{114} \mathrm{C}$-glucose by adipose tissue in rats adapted to periodic hyperphagia and in control rats fed ad libitum. Incorporation of ${ }^{14} \mathrm{C}$-radioactivity into lipids is expressed as counts/min. mg protein. Each value is the mean for six animals \pm standard error of mean

\begin{tabular}{|c|c|c|c|c|}
\hline \multirow[b]{2}{*}{ Feeding pattern } & \multicolumn{4}{|c|}{ Insulin administered ( $\mu \mathrm{U} / 100 \mathrm{~g}$ body wt.) } \\
\hline & 0 & 125 & 500 & 1000 \\
\hline $\begin{array}{l}\text { Ad libitum } \\
2 \mathrm{~h} / \mathrm{day}\end{array}$ & $\begin{array}{l}785.5 \pm 88.7 \\
736.6 \pm 88.6\end{array}$ & $\left.\begin{array}{r}802.1 \pm 80.0 \\
1580.1 \pm 137.5\end{array}\right\}^{a}$ & $\left.\begin{array}{l}1181.1 \pm 299.3 \\
2064.5 \pm 449.1\end{array}\right\} \mathrm{b}$ & $\left.\begin{array}{r}4675.0 \pm 547.9 \\
12134.8 \pm 1122.4\end{array}\right\}$ \\
\hline
\end{tabular}

a $P<0.001$ b $P<0.2$

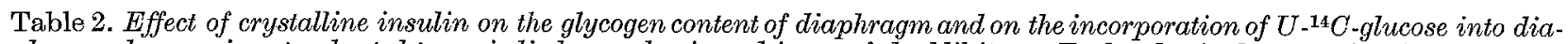
phragm glycogen in rats adapted to periodic hyperphagia and in rats fed ad libitum. Each value is the mean for six animals \pm standard error of mean

Insulin administered ( $\mu \mathrm{U} / 100 \mathrm{~g}$ body wt.)

\begin{tabular}{|c|c|c|c|c|c|c|c|c|}
\hline \multirow{2}{*}{$\begin{array}{l}\text { Feeding } \\
\text { pattern }\end{array}$} & 0 & 125 & 500 & 2000 & 0 & 125 & 500 & 2000 \\
\hline & \multicolumn{4}{|c|}{ glycogen content (mg/100 g wet wt.) } & \multicolumn{4}{|c|}{${ }^{14} \mathrm{C}$-incorporation (counts/min. mg glycogen) } \\
\hline $\begin{array}{l}\text { Ad libitum } \\
2 \mathrm{~h} / \mathrm{day}\end{array}$ & $\begin{array}{r}299.8 \\
\pm \quad 20.4 \\
321.0 \\
\pm \quad 6.2\end{array}$ & $\begin{array}{r}359.3 \\
\pm \quad 7.0 \\
381.8 \\
\pm \quad 22.8\end{array}$ & $\begin{array}{r}519.1 \\
\pm \quad 23.1 \\
495.0 \\
\pm \quad 10.5\end{array}$ & $\begin{array}{r}658.3 \\
\pm \quad 26.3 \\
664.5 \\
\pm \quad 26.9\end{array}$ & $\begin{array}{r}905.0 \\
+227.6 \\
644.0 \\
\pm 197.3\end{array}$ & $\begin{array}{r}5365.0 \\
+\quad 905.2 \\
5619.0 \\
+\quad 843.1\end{array}$ & $\begin{array}{r}12330.0 \\
\pm \quad 1713.6 \\
13196.0 \\
\pm \quad 1224.0\end{array}$ & $\begin{array}{r}15669.0 \\
\pm \quad 990.4 \\
14657.0 \\
\pm \quad 2235.0\end{array}$ \\
\hline
\end{tabular}

water, part of the solution was used for assessing the glycogen content by means of the anthrone reagent (CARRoLl et al., 1956), and part was used for measuring its radioactivity by scintillation counting in Bray's medium (BRAY, 1960). Parametrial adipose tissue was homogenized in methanol, and the total lipids were extracted using Folch's method (FoLCH et al., 1957). Protein in adipose tissue was estimated by Lowry's method (LownY et al., 1951). The radioactivity of the

\footnotetext{
1 Supplied by Institute for Research, Production and
} Users of Radioisotopes, Prague, Czechoslovakia. animals in those groups where the administered saline did not contain insulin. The incorporation of labelled glucose into the lipids of adipose tissue was, with all the doses of insulin used, 2-3 times greater in the adapted rats than in the control rats fed ad libitum. The greater sensitivity to insulin of adipose tissue from adapted rats was particularly marked with a dose of $125 \mu \mathrm{U}$ of insulin/100 g, where there was a doubling of the incorporation of labelled glucose into lipids of adipose tissue, whereas the adipose tissue of rats fed ad libitum did not respond to this dose. 
On the other hand, we did not find any difference between adapted and control rats as regards the sensitivity of the diaphragm to insulin (Table 2). It is obvious from the data in Table 2 that there are no significant differences between adapted and control rats, whether or not the administered saline contained insulin, as regards the glycogen content of the diaphragm or the incorporation of labelled glucose into diaphragm glycogen. adapted rats were smaller than fat cells of controls, and thus per unit of weight or volume there was also a greater cell surface. This altered tissue was more sensitive to the lipogenetic stimulus of insulin, and also to lipolytic stimuli, e.g. adrenaline (BRAUN et al., 1966).

In the increased sensitivity of adipose tissue for insulin, humoral factors that potentiate the effect of insulin on adipose tissue probably do not participate; in other experiments, where we investigated the serum

Table 3. Effect of crystalline insulin on the glycogen content of incubated diaphragms isolated from rats adapted to periodic hyperphagia and from rats fed ad libitum. Each value is the mean for six diaphragms \pm standard error of mean

\begin{tabular}{|c|c|c|c|}
\hline & \multirow[t]{2}{*}{ Feeding pattern } & \multicolumn{2}{|c|}{$\begin{array}{l}\text { Glycogen content of diaphragm } \\
\text { (mg/100 g wet weight) }\end{array}$} \\
\hline & & Without insulin & With insulin \\
\hline Exp. I & Ad libitum & $241.0 \pm 17.6$ & $342.7 \pm 16.7$ \\
\hline Exp. II & Ad libitum & $317.5 \pm 20.8$ & $528.2 \pm 31.9$ \\
\hline & $2 \mathrm{~h} / \mathrm{day}$ & $305.0 \pm 31.9$ & $570.5 \pm 24.0$ \\
\hline
\end{tabular}

In experiment (I) diaphragm was incubated for $120 \mathrm{~min}$ in $3 \mathrm{ml} \mathrm{KRB}$ buffer, containing $15 \mu$ moles glucose and $7.5 \mathrm{mg}$ bovine serum albumin without hormone or with $10000 \mu \mathrm{U}$ insulin per $\mathrm{ml}$.

In experiment (II) diaphragm was incubated for $120 \mathrm{~min}$ in $3 \mathrm{ml} \mathrm{KRB}$ buffer, containing $60 \mu$ moles glucose and $7.5 \mathrm{mg}$ bovine serum albumin without hormone or with $100000 \mu \mathrm{U}$ insulin per $\mathrm{ml}$.

The reactivity of the diaphragm to insulin in vitro (Table 3 ) was similar. We did not find significant differences between adapted and control rats, either in the absence or in the presence of insulin, in experiments using two different concentrations of glucose and insulin in the incubation medium.

\section{Discussion}

Adipose tissue of adapted rats compared with that of controls fed $a d$ libitum responded more sensitively to small doses of insulin given intraperitoneally, acting locally and not affecting the blood sugar level, just as had been shown using hypoglycaemic doses of insulin. Muscle tissue, on the other hand, responded to insulin under these conditions in the same way in adapted rats as in controls fed ad libitum. A rather similar position as regards the enhanced sensivity of adipose tissue to insulin was described by STAUFEaCHER in mice with hereditary obesity; in that model, however, the sensitivity of muscle tissue to insulin declines further (STAUFFACHER et al., 1965).

In addition to many metabolic changes which are typical of adipose tissue of rats adapted to periodic hyperphagia (FÁBRY, 1967), this tissue also differed from the adipose tissue of controls fed ad libitum in its composition (BraUn et al., 1965; BraUd et al., 1967) and morphological aspects (BRAUN et al. 1965). Compared with adipose tissue of controls, it contained more RNA and was more cellular, as suggested by the higher DNA content per mg tissue as well as per fat body, and by the histological appearance of the tissue. Fat cells of insulin-like activity of adapted rats by the effect on adipose tissue, we did not find differences in the serum insulin activity between rats adapted to periodic hyperphagia and controls fed ad libitum (VRÁNA et al., 1968).

If we consider the role of insulin in accentuated lipogenetic and other anabolic processes in adipose tissue of rats adapted to periodic hyperphagia, we must consider in addition to the reactivity of the target organ to the hormone also the secretory capacity of the endocrine pancreas and the serum insulin concentration. When investigating the secretory response of the insular apparatus to administered glucose, using as the criterion the serum insulin concentration after a glucose load, we did not find any differences between rats adapted to periodic hyperphagia and controls (VRÁra et al., 1968). Owing to ingestion of large amounts of food within a short period of time and owing to accentuated intestinal absorption of the main physiological stimulus for insulin secretion, glucoseadapted rats develop a prompt, short-term rise in serum insulin concentration, a periodic hyperinsulinaemia (VRÁNA et al., 1968).

In view of the fact that adipose tissue of adapted rats responds much more sensitively to insulin even in the doses corresponding to a hormone concentration in the medium to which the tissues are exposed, and in view of the high concentration of serum insulin in the absorption stage of digestion, we may assume an important role of insulin in the mechanism of adaptive hyperlipogenesis in rats adapted to periodic hyper- 
phagia. By interplay of regulatory changes at the level of hormone secretion as well as at the level of the target tissue reactivity, a situation develops which is from the energetic aspect favourable for the infrequently fed animal. In the absorption stage anabolic processes in adipose tissue are potentiated, their final effect being the maximum conversion of carbohydrate into lipids and their deposition.

\section{References}

BraUN, T., P. FábrY, and L. Kazdová: Influence of feeding frequency on the composition of adipose tissue and the mobilisation of depot fat. Proceeding of the VIIth International Congress of Nutrition, Hamburg, 1966, vol. II, p. 249. Braunschweig: Friedr. Vieweg \& Sohn (1967).

- L. KAZDová, and P. FÁBRY: The effect of the frequency of food intake on the protein and nucleic acid content of rat adipose tissue. Physiol. bohemoslov. 14, 559-562 (1965).

- A. VRáNA, and P. FÁBRY: Enhanced hypoglycemic effect of exogenous insulin associated with an increased response of adipose tissue and a diminished response of the diaphragm in "meal fed" rats. Experientia 23, $468-470$ (1967).

BrAY, G.A.: A simple efficient liquid scintillator for counting aqueous solutions in liquid scintilation counter. Analyt. Biochem. 1, 279-285 (1960).

Carrol, N.V., R.W. Longley, and J.H. Roe: The determination of glycogen in liver and muscle by use of anthrone reagent. $J$. biol. Chem. 220, $583-593$ (1956).

FÁBRY, P.: Jednoduchý systém standartních laboratorních diet s rủzným podílem hlavních živin. Čsl. Fysiol. $8,529-533(1959)$.
- Metabolic consequences of the pattern of food intake. In Handbook of Physiology-Alimentary Canal I, p. 31. Washington, D.C.: Amer. Phyiol. Soc. 1967.

Folch, J., M. Lees, and G.H. SLOANE-STANLEY: A simple method for the isolation and purification of total lipids from animal tissues. $J$. biol. Chem. 226, 497-509 (1957).

Lowry, O.H., N.J. RosmNBROUGH, A.I. FARR, and R.J. RANDALL: Protein measurement with the folin phenol reagent. J. biol. Chern. 193, 265-275 (1951).

RAFAFLSEN, O.J.: Glycogen content of rat diaphragm after intraperitoneal injection of insulin and other hormones. Acta physiol. scand. 61, 314-322 (1964).

- V. LAURIs, and A.E. Renold : Localized intraperitoneal action of insulin on rat diaphragm and epididymal adipose tissue in vivo. Diabetes 14, 19-26 (1965).

Stauffacher, W., O.B. Crofford, B. Jeanrenaud, and A.E. RENond: Comparative studies of muscle and adipose tissue metabolism in lean and obese mice. Ann. N. Y. Acad. Sci. 131, 528-540 (1965).

VRÁNA, A., T. BraUN, P. FÁBRY: Changes in the insulin level assessed by radioimmunological and biological methods in serum of rats adapted to periodic hyperphagia. Čsl. Fysiol. 17, 28-29 (1968) (in Czech).

- P. FÁBRY, and T. BRAUN: Periodic hyperinsulinaemia in meal fed rats. Physiol. bohemoslov. 17, 498-499 (1968).

\author{
A. VRÁNA \\ P. FÁBRY \\ T. BraUN \\ Institute of Human Nutrition \\ Physiology Department \\ Budějovická 800 \\ Prague 4 - Krč, Czechoslovakia
}

